\title{
THE OTHER AS A SOURCE OF KNOWLEDGE AND A REFERENCE POINT FOR THE LEARNING ADULT
}

\author{
JERZY SEMKÓW \\ Wyższa Szkoła Pedagogiczna im. Janusza Korczaka w Warszawie \\ Janusz Korczak Pedagogical University in Warsaw \\ Wydział Nauk Społeczno-Pedagogicznych w Katowicach \\ ul. Katowicka 27, 40-173 Katowice \\ Email: jerzysemkow@gmail.com \\ ORCID: 0000-0002-3618-1857
}

\begin{abstract}
Aim. The aim of this paper is to discuss the possibility of adult learning by way of communicating with the representatives of other nations, cultures, and religions.

Methods. The method used in the paper consists in the analysis of scholarly opinions wherein authors point out at the role of the Other human being in the process of our getting to know the world (from childhood: parents, neighbours - to the older age: people from different nations and cultures). The theory of learning introduced by Albert Bandura and Joanna Rutkowiak is utilized as a theoretical background.

Results. The relation with the other can take many forms and fulfil different, albeit important in terms of education and functions. The other is a person who in numerous life situations becomes a source of knowledge for the learning adult, at the same time playing a role of a specific reference point. The recognition of the value of such resources acquires special meaning in the current situation wherein one can observe the emergence of attitudes of xenophobia and chauvinism. Moreover, learning through intercultural interactions can be seen as an effective way of gaining knowledge about the world of rapid changes.

Conclusions. The paper concludes with the following questions:

1. To what extent does the rising atmosphere of intolerance impoverish the cognitive sphere of the adult learner?

2. In what way does the lack of acceptance of the Other destroy the field of sensitivity of the adult person?

3. What are the prospects - given the current socio-political climate in Poland - and what kind of possibilities can be opened by the dialogical strategy of understanding Otherness?
\end{abstract}

Key words: the Other, learning adult, learner, migration 


\section{LEARNING IN A WORLD OF CIVILIZATIONAL ACCELERATION}

$\mathrm{T}$

he social and cultural context of our lives often stuns us with its volatility. Yet, if we were to take account of the ways this situation is described by the representatives of different age generations, it would turn out that the disparity of our views on reality takes its roots not only in age-related life experiences but also, and equally, in the rapid process of filling our closer and more distant environment with ever new civilizational and cultural commodities. Younger generations effortlessly adopt new technologies of communication, along with their inherent post-modern cultural meaning rendering them absolutely normal and understandable. At the same time, older generations - especially those whose youth was played out in the era of "real socialism" - struggle to keep up with the pace of the changes and react to the rushing reality with either an attitude of complete closure, or forthright objection. Only a few attempt to really keep up in order to be able to respond to the changes by way of learning. Much seems to indicate that this accelerated process of filling modern people's lives with newer and newer goods and the accompanying progress of life's changeability makes learning acquire a significance of a factor that can determine the very quality of human life at every age.

Within the main premises of modern reality thus depicted, one can point to the opportunities that arise from numerous social encounters that the individual experiences from his/her childhood on and whose intensification may possess a particular educational value in the adult life. The problem that is manifested here could be illustrated in a question: how can the learning adult utilise the knowledge that people he/she meets on his life's path have, especially as representatives of other ethnicities and religions? The term: "source of knowledge" has in this paper a metaphorical meaning. It is most usually restricted to cases in which there is a talk about the "materials that constitute the knowledge resource in a given field", or when we think of "the people who give us certain true information" on the things we take our interest in (Słownik Języka Polskiego, 1989, p. 1081).

People who were raised in different, sometimes distant cultures from ours, and having a substantial experience and knowledge gathered thereof often become vehicles of useful information for us, thanks to their otherness. In this sense, we can perceive them as reference points: as persons with whom we compare ourselves in terms of the knowledge (information) possessed on a given thing, object or issue. In other words, the other as a possessor of knowledge or even information on an issue that interests us may in many cases be indispensable.

The considerations included in this paper, are a result of an unforeseeable course of events occurring in our social and educational context. Scholarly literature and relatively rich teaching experience was helpful in their analysis. 


\section{THE OTHER - IT MEANS WHO?}

Who then is this "Other" who becomes the source of knowledge for us and fulfils the function of the point of reference for the learning adult? "The Other", looked upon as someone significant in the real world, only seemingly has lost his importance and ceased to be the provider of the knowledge about reality. If we were to look at this problem from a child's perspective, and then from the perspective of a young human being, it will not be difficult to notice that "otherness" constantly emanates a compelling glare of something unknown, hidden, close to a secret which tempts and encourages knowing it. The child usually sees this "otherness" in its mother or father who at the first stage of his/her life are the main source of getting to know both the closest environment and things more distant. Due to their proximity, both the father and the mother become points of reference for their offspring; they allow for the search for similarities and differences between the son or the daughter and their parents. This process of comparing and finding satisfaction in realising the similarities and differences often makes of the parents "significant others" who by way of their authority exert an influence on the mind and behaviour of their children, teaching them how to navigate through complex reality.

Drawing on the conclusion that direct intergenerational transfer is best enhanced within the family environment, one cannot ignore the facts to which research points. One of newer theories of Albert Bandura „assumes that an individual is inclined to follow and subordinate himself to people whom he perceives - in regard to functions they fulfill - as carriers of model social behaviour, as "social models" (Hurellman, 1994, p. 24). For a child and often for a young individual one of the parents or both of them represent patterns of social behaviour and function as examples of proper attitudes and in this sense they can act as "significant others"

It happens that the "significant other" becomes a person from the neighbourhood, a peer, or someone we met when we entered different environments. "The other" may also be a pattern of character not only for a young individual. It can also be people from different cultures, representatives of other nations and religions whose civilisational and cultural situation acutely differs from ours. We then enter a problematic of extraordinary scale whose specificity cannot be discussed within the limited frame of this article. The phenomena of multiculturalism and cross-cultural encounters, analysed not only in sociological research, have been of interest to scholars from the very beginnings of system transformation in Poland. ${ }^{1}$

In the face of the invasion of popular culture and virtual reality, the Other often takes a fictitious shape. Our fascination with literature and film heroes, or figures from the virtual world of the Internet may open the path to learning something new (or dropped earlier on), because a character pat-

1 This problematic has been taken up in the works of authors such as: P. Grzybowski (2007); T. Paleczny (2005); W. Kalaga (2004); E. Możejko (2004); Z. Melosik (2007). 
tern, when suggestively designed, has a compelling power (Spychalska-Kamińska, 2012, p. 199-207). Doubtless, in the expansion of the Internet we observe its encompassing ever wider areas of knowledge, a token of a completely new situation; knowledge, which not so long ago used to be preserved on paper pages of books and journals, but nowadays available on pages of Internet portals. The advantage of the "Internet print" is measured with time necessary to publish a text in this quick medium. ${ }^{2}$ One can see in this fact "cultural consequences of globalisation", as - as Anthony Giddens (2001) argues - „images, ideas, goods and styles spread faster than ever before" (p. 85). Not all, however, see in the Internet only a source of quick information and knowledge; some critics point to numerous dangers arising from tendencies to abuse this medium (Ćwikliński, 2005; Orliński, 2013).

"The Other" can also be perceived wider, when "otherness" gets to be seen not only in terms of certain physical and personal distinctiveness, but also as an unknown area of expertise that manifests itself in a new theory or in a new fragment of social life. Thus understood otherness means transferring the principles restricted so far to people (particular persons) to intellectual products of these people, as well as to their social activity. Discussing the role of "the Other" in pedagogy, Alicia Kargulowa (2011) focuses on the moment of our reaction to the "other". She draws on Claude Levi-Strauss's distinction of two strategies of our dealings with "the other" - antropoemic (dismissal) and antropophagic (acquisition, assimilation) and argues that we need to think of the third strategy which would amount to dialogue, to our comparing ourselves with the "other" and exchanging and in this way creating a new "Other" value. Instead of dismissing the "other" by negating his/her separation and instead of acquiring or assimilating the "other" with all its consequences - it is obligatory to situate him on the grounds of dialogue which will allow both the "other" and his interlocutor to maintain their identities. This dialogue should accompany or perhaps even precede anthropoemic and anthropophagic strategies. The dialogue strategy developed by A. Kargulowa (2011) is based on an assumption that "it is the very presence of the other that allows us to better know ourselves, define our qualities and shape our identity" ( $p$. 73). It follows then, that the "other" as a source of new knowledge for us presents us with an opportunity to not only gain a better orientation in a narrow fragment of reality, but also to more fully recognise our own self and identity; and it is in this way that the "other" may become a reference point for an adult individual.

2 It is therefore unsurprising that the possibility of immediate presentation of new elements of knowledge made the publishing house of the famous British Encyclopedia resign from editing the paper version and replace it with the online one. 


\section{LEARNING AS A NECESSARY CONDITION OF CONSCIOUS EXISTENCE}

A commonly known psychological definition of learning reads that it is: „a process whereby an individual acquires relatively solid changes in behaviour in the course of his/her individual experiences" (Włodarski, 1998, p. 860). Human beings, having had different experiences and their subjective receptions, acquire some elements of knowledge about the world which means that they internalise particular visions of how it was and how it is at a particular time or how it could be and how it will be in the future.

Ronald D. Davis points to different aspects of learning. Referring to The New Lexicon Webster's Dictionary, he writes that "to learn" means "to acquire knowledge or skills in some area by studying, exercising or by way of tutelage or experience; to commit something to memory, to get to know something or become aware of something" (Davis \& Braun, 2006, p. 20). The intense character of the process of internalisation of knowledge depends on many factors. Of great, if not fundamental, importance is the problem of the value of the knowledge that is transmitted and internalised. The social status of knowledge is well described by the definition which argues that "it is the totality of information possessed by a person or by a group of people or a culture" (Reber \& Reber, 2005, p. 864). Knowledge in its narrow sense is "the totality of information about the reality along with the capacity of its usage" and thus understood "it is first of all, although not exclusively, scientific knowledge" (Nowa Encyklopedia Powszechna, 1997, p. 733).

It seems that the knowledge which becomes the aim of our conscious endeavours - filling some blank space and in this way helping us to understand a given element of reality - takes on a subjectively higher value. Not only do we treat it as an important good in its cognitive function, but also as a factor that reinforces the conviction of the learner as to the significance of systematic contact with the galloping influx of information about the world. It is one of the ways of building a positive attitude to the process of gathering knowledge and perhaps is best illustrated by an expression of "the joy of learning." Gordon Dryden and Janette Vos emphasise this point when they propose to make the value of any system of education dependent on its capacity to "instill in people the joy of learning" (Dryden \& Vos, 2003, p. 107). Contemporary research shows that in Polish schools the respect for knowledge is not instilled in students and the joy of learning is a rarity. The long term experiences of the author of this essay allows me to conclude that much more often we can observe this joy in learning adults who are aware of their role as learners. Confronted with the speed of changes in the course of their lives, adults foster a desire to learn which they look upon as a priority. Then they choose an individual educational path (formal or informal) and get to experience positive emotions built on a conviction that despite sometimes advanced age, they can internalise new content and obtain in this way a better understanding of ongoing processes 
and changes. At the margin it is worth noticing that at present the learning or studying adult in principle wants to widen his/her perspectives in such a way that the knowledge and skills he gains bring him benefits no only in his profession, but also within the dimension of his personal development. This is what separates him from those who were studying before the system transformation, when receiving a diploma used to be enforced chiefly by the pressure on the part of the employer. ${ }^{3}$

\section{LEARNING FROM THE OTHER}

There is no doubt that today we live at a time of rapid changes and the resulting complications "which are extremely hard to describe and define." "It is even more difficult to think of universal social mechanisms and rules that will at least partly foresee the processes, activities or directions of social changes (Bogunia-Borowska, 2008, p. 53). An active individual becomes an element of an intensifying net of dependencies on the world of things and most of all, on other people. Inscribed in formal social structures and personal, informal relations, he tries to keep the main attributes of his identity. The younger generations find themselves in a peculiar situation; their path to maturity turns out to be incomparably more difficult than the one of their peers fifty or sixty years earlier. The multiplicity of life pathways offered especially by expansive media only seemingly widens the possibility to choose sociably useful alternatives. Therefore, the decision on the choice of such a life trajectory which seems to guarantee to a young individual a reasonable personal development becomes a serious problem.

Now it might be argued that beside the parents and people from the closest environment, the Others may be helpful in making this difficult choice. People culturally different with whom even momentary contact allows one to extend his or her cognitive horizon, at first may function as outsiders. But learning from such people has still a value of novelty: of gaining something original and powerfully engraved in our memory. Joanna Rutkowiak calls this way of collecting knowledge about the world "learning from the outsider." Learning form the Other does not always bring benefits, since this process may be accompanied by certain constraints (Rutkowiak, 1997, pp. 86-87). J. Rutkowiak goes on to distinguish in such a relation four possible "components of our relations with the Other".

And so, beside "the cognitive relation" we have the "ethical," "pragmatic", and "personal-co-creative" ones (Rutkowiak, 1997, pp. 92-94). In the cognitive aspect of our relation with the Other it is assumed that the condition sine qua non of learning from the other is getting to know him which can carry serious consequences. Let us nevertheless focus on the ethical and personal-co-creative

3 The author of this paper participated in the 1980s in courses for employees from state workplaces who openly complained about the constraint enacted upon workers, connecting the prospect of their promotion to completing that form of education. Therefore, they manifested attitudes of indifference and ambivalence. 
aspects. In our contact with the Other, of major importance is recognition of his subjectivity which is the warrant of the symmetrical character of the encounter. It is then when the knowledge whose source the other human being is, gains its value; subjectifying through balancing the outsider's position becomes the starting point of seeing the knowledge he possesses as something valuable. J. Rutkowiak is right when she notices that the outsider's difference, his alterity creates the chance for an effective intersubjective contact by way of relating to one another "face to face" (Rutkowiak, 1997, p. 93).

As to the personal-co-creative character of the relation, one can say that it fulfills the function of "the catalyst of the subject's self-formation" (Rutkowiak, 1997, p. 93). We are dealing here with a situation when the outsider is represented not only by a teacher, or a neighbour, but also by a colleague or a complete stranger. In the educational practice of adults we can observe a curious phenomenon when an outsider accepted by the learners (students) brings about a gradual change in their attitude to knowledge and learning - from a negative, to a positive one. J. Rutkowiak explains a reverse situation when the Other works in such a way that triggers resistance in the learning adult which may indirectly result in vehement change of attitudes, beliefs and opinions of the student. ${ }^{4}$

Our understanding of otherness and the way we react to representatives of other nations depends on many factors both at the micro- and macro level. With the Other - conceived as a foreigner, a stranger - we have been slowly accustoming ourselves since the beginning of system transformation, although the process has now accelerated. The attitudes of xenophobia, once intensely propagated against the Western cultures - have now been neutralized. Rapidly developing international tourism and cultural, commercial and sport exchanges allow us to obtain more and more important information. A different culture, uncommon habits made of the outsider an intriguing figure worthy of interest but also acceptance. In this situation, the knowledge received by way of encountering civilizational, social, and cultural difference has gained a value of freshness and power conducive to tolerance and openness.

On the other hand, however, as a result of global immigration policy and intensification of terrorist acts, a large part of the European public attributes to the Other negatives traits. From a figure of interest, arousing friendly feelings, he morphs into an unwanted liability, someone dangerous, unpredictable. In this growing antipathy for the outsider, his educational potential disappears. Naturally, he does not cease to function as a source of knowledge, but now it is the knowledge that situates him in a sphere of bad intentions and sinister plans. The features of the Other exposed in the media render him in public awareness a source of threat and anxiety. Meanwhile, the theory of interhuman space, exquisitely explained by Piotr Sztompka (2016), emphasizes that "the society is first of all that which takes place between the individuals" which means also between people who represent different nations, different lifestyles, habits and mores (Sztompka, 2016, p. 333). Sztompka's second thesis distinctly marks

4 This aspect of learning is emphasised in the theory of resistance by H. A. Giroux (1991). 
that "we are what we have received from the others whom we have met in our lives" (Sztompka, 2016, pp. 33-40). Only these two theses, along with the remaining six ${ }^{5}$ make us aware of the huge role played by the relations between individuals and groups that constitute the core of interhuman space. In these relations the Other - as a human being with his cultural and educational potential who co-creates social capital - remains an inalienable value.

Coming to the end of these considerations, it is worth asking one essential question: how does the reaction of modern society to the mass immigration movement influence the role of the Other as a potential source of our knowledge about the world? This question is followed by another one: can the Other - who in common opinion begins to acquire a threat status - be a point of reference for the learning adult? The answer to these questions is YES: the learning adult tries to obtain knowledge which will allow him to figure out his own position in this matter. He often uses different sources of information in order to verify his negative image of the Other. Three possible attitudes to the Other could now be systematised as follows:

Rejection: the Other is seen as someone who puts in danger social and cultural security and Christian civilization;

Ambivalence: the Other is perceived in a twofold way; our feelings toward him are contradictory - when we witness the tragedy of Syrian families, we want to help, when we are confronted with images of terror, we become enemies of the Other;

Acceptance: we see in the Other another human being with his aims and characteristics which make of him a person worthy of respect (Ćwieluch, 2017, pp. 27-29).

Therefore there arise the following questions:

1. To what extent can it be argued that growing intolerance impoverishes cognitive potential of the learning adult?

2. In what way does intolerance of the Other disrupt ethical sensibility of the adult person?

3. What possibilities does the strategy of dialogue with the Other introduce to our current socio-political situation?

5 Third thesis: "the group is such as the relations that bind its members". Fourth thesis: "for the shaping of individual and group characters the system of relations in the interhuman space is decisive". Fifth thesis: "the effectiveness of individuals and groups and the level of their satisfaction from social life depends on the level of social capital possessed". Sixth: in concrete cases the life chances of individuals and groups depend on unique balance positive and negative relations and especially moral and immoral". Seventh: "Every creative change on the level of individual biography or on macro-level of history has its roots in interhuman space, and its chances depend on the level of social capital, individual and collective". Eighth: "the key to wellbeing and happiness of a society lies in positive social relations in a good interhuman space and thick moral space (Sztompka, 2016, p. 335-336). 


\section{REFERENCES}

[1] Bogunia-Borowska M. (2008). Codzienność życia społecznego - wyzwania dla socjologii XXI wieku. In P. Sztompka, \& M. Bogunia-Borowska (Eds.), Socjologia codzienności (pp. 53-91). Kraków: Wydawnictwo Znak.

[2] Ćwieluch J. (2017, July 12)., Polityka, 28, pp. 27-29

[3] Ćwikliński A. (2005). Zmiany w polskiej edukacji w okresie globalizacji, integracji i transformacji systemowej. Poznań: Wydawnictwo UAM.

[4] Davis, R. D.\& Braun, E. M. (2006). Dar uczenia się. Poznań:ZyskiS-ka Wydawnictwo.

[5] Dryden G. \& Vos J. (2003). Rewolucja w uczeniu. Poznań: Zysk i S-ka Wydawnictwo.

[6] Giddens A. (2001). Nowoczesność i tożsamość. "JA" i społeczeństwo w epoce późnej nowoczesności. Warszawa: Wydawnictwo Naukowe PWN SA.

[7] Giroux H. A. (1991). Reprodukcja, opór i akomodacja. In Z. Kwieciński (ed.), Nieobecne dyskursy (pp. 13-37) Torun: Wydawnictwo UMK.

[8] Grzybowski P. (2007). Edukacja europejska - od wielokulturowości do międzykulturowości. Kraków: Oficyna Wydawnicza Impuls.

[9] Hurrelman K. (1994). Struktura społeczna a rozwój osobowości. Poznań: Wydawnictwo UAM.

[10] Kalaga W. (2004). Obowiązek Innego. Trzeci. In W. Kalaga (ed.), Dylematy wielokulturowości (pp. 41-65). Kraków: Wydawnictwo Universitas.

[11] Kargulowa A. (2011). Inny w pedagogice. In T. Hejnicka-Bezwińska (ed.), Pedagogika ogólna. Dyskursy o statusie naukowym i dydaktycznym (pp. 77-80). Bydgoszcz: Wydawnictwo Uniwersytetu Kazimiera Wielkiego.

[12] Melosik Z. (2007). Teoria i praktyka edukacji wielokulturowej. Kraków: Oficyna Wydawnicza Impuls.

[13] Możejko E. (2004). Wielka szansa czy iluzja: wielokulturowość w dobie ponowoczesności. In W. Kalaga (ed.), Dylematy wielokulturowości (pp. 141-161). Kraków: Wydawnictwo Universitas.

[14] Nowa Encyklopedia Powszechna PWN (1997). T. 6 (S-Z). Warszawa: Wydawnictwo Naukowe PWN.

[15] Orliński W. (2013). Internet. Czas się bać, Warszawa: Wydawnictwo Agora.

[16] Paleczny T. (2005). Stosunki międzykulturowe. Zarys problematyki. Kraków: Wydawnictwo Uniwersytetu Jagiellońskiego.

[17] Słownik Języka Polskiego PWN (1989), (ed.) M. Szymczak, vol. III, Warszawa: PWN.

[18] Reber A. S. \& Reber E. S. (2005). Stownik psychologii, Warszawa: Wydawnictwo Naukowe SCHOLAR.

[19] Rutkowiak J. (1997). Szanse i bariery uczenia się od outsidera. In. Uczenie się od outsidera. Perspektywa europejskiej wspótpracy edukacyjnej, (red. J. Rutkowiak). (pp. 85-131), Kraków: Oficyna Wydawnicza Impuls.

[20] Spychalska-Kamińska I. (2012). Znaczenie idoli w rozwoju tożsamości młodzieży, w okresie wczesnej adolescencji. In A. Gromkowska-Melosik, \& Z. Melosik (eds.), Tożsamość w społeczeństwie wspótczesnym: pop-kulturowe [re]interpretacje (pp. 199206). Krak: Oficyna Wydawnicza Impuls.

[21] Sztompka P. (2016). Kapitał społeczny. Teoria przestrzeni międzyludzkiej, Kraków: Wydawnictwo Znak.

[22] Włodarski Z. (1998). Psychologia uczenia się, Warszawa: Wydawnictwo PWN. 